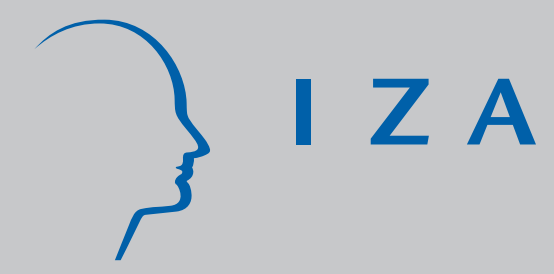

IZA DP No. 552

Estimations of Occupational and Regional Matching Efficiencies Using Stochastic Production Frontier Models

René Fahr

Uwe Sunde

August 2002 


\title{
Estimations of Occupational and Regional Matching Efficiencies Using Stochastic Production Frontier Models
}

\author{
René Fahr \\ IZA Bonn and University of Bonn \\ Uwe Sunde \\ IZA Bonn and University of Bonn
}

Discussion Paper No. 552

August 2002

IZA

P.O. Box 7240

D-53072 Bonn

Germany

Tel.: +49-228-3894-0

Fax: +49-228-3894-210

Email: iza@iza.org

This Discussion Paper is issued within the framework of IZA's research area Evaluation of Labor Market Policies and Projects. Any opinions expressed here are those of the author(s) and not those of the institute. Research disseminated by IZA may include views on policy, but the institute itself takes no institutional policy positions.

The Institute for the Study of Labor (IZA) in Bonn is a local and virtual international research center and a place of communication between science, politics and business. IZA is an independent, nonprofit limited liability company (Gesellschaft mit beschränkter Haftung) supported by the Deutsche Post AG. The center is associated with the University of Bonn and offers a stimulating research environment through its research networks, research support, and visitors and doctoral programs. IZA engages in (i) original and internationally competitive research in all fields of labor economics, (ii) development of policy concepts, and (iii) dissemination of research results and concepts to the interested public. The current research program deals with (1) mobility and flexibility of labor, (2) internationalization of labor markets, (3) welfare state and labor market, (4) labor markets in transition countries, (5) the future of labor, (6) evaluation of labor market policies and projects and (7) general labor economics.

IZA Discussion Papers often represent preliminary work and are circulated to encourage discussion. Citation of such a paper should account for its provisional character. A revised version may be available on the IZA website (www.iza.org) or directly from the author. 
IZA Discussion Paper No. 552

August 2002

\section{ABSTRACT \\ Estimations of Occupational and Regional Matching Efficiencies Using Stochastic Production Frontier Models}

By applying a stochastic production frontier approach to the matching process of unemployed and vacancies, this paper provides novel detailed insights into the process of job creation. For different labor markets as defined by occupation and region, the methodology produces estimates of the relative importance of demand and supply factors for the creation of new jobs, and of the overall efficiency of job creation. Some crucial determinants of the overall matching efficiency are identified and analyzed. This allows to make differentiated statements about the appropriateness of labor market policies, and therefore provides policy makers with novel relevant information.

JEL Classification: J64, C24

Keywords: matching efficiency, stochastic frontier, occupational unemployment, regional unemployment

Uwe Sunde

IZA

PO Box 7240

53072 Bonn

Germany

Tel.: +49 2283894533

Fax: +492283894210

Email: sunde@iza.org 


\section{Introduction}

Most European labor markets are characterized by high and persistent levels of unemployment. With intent to reduce unemployment, many different proposals of how legislation and governments could and should actively intervene have been publicly discussed. The proposals contain essentially similar policy recommendations, albeit with different priorities. The suggestions are based on the respective assessments of the causes of high unemployment and the allegedly most effective cure for the problem. Two main lines of arguments can be distinguished: One focuses on the labor supply side and blames insufficient incentives for unemployed to search actively and a rigid, inefficient labor market in terms of matching unemployed job seekers with vacant jobs for being responsible for pervasive and persistent unemployment. Policy suggestions in this respect include reforms of the design of unemployment insurance and improvements in the efficiency of the matching process and of job placements of employment offices. The other line of argument blames insufficient labor demand and seeks to alleviate the unemployment problem by policies that promote the creation of new jobs and vacancies. However, neither of the rival schools of thought has provided thorough empirical evidence why their respective point of view is the correct one. Nor are there many scientific contributions guiding the policymaker as to which action is advisable for which (sub-)labor market.

This study provides novel information about the efficiency of the matching process of unemployed job seekers and vacancies on different labor markets. Labor markets are defined by occupation or by region. The primary aim is to analyze efficiency as well as determinants of inefficiencies. Such information is required for making policy recommendations, regardless which of the formerly mentioned groups is concerned. The detailed investigation of matching efficiency and the determinants of the matching process complements an analysis of matching elasticities and the relative importance of demand and supply factors in the matching process presented in earlier contributions, see Fahr and Sunde (2001b). This study is therefore meant as a guide for the policy maker to identify occupations or regions where labor market policies might be indicated, and where not. As in the literature on job matching, the flow of new hires per period in a certain occupation or region is interpreted as a function of the stocks of unemployed job seekers and posted vacancies in analogy to the production process of a firm. The assumption that this process of job creation is efficient in the sense that, given the frictions on the labor market incorporated in this matching function, the maximal number of matches between unemployed and vacancies is created, is debatable. If the process is inefficient, then, from a policy point of view, it would be important to know how inefficient matching on the labor market is, and what determines this inefficiency.

Following Warren (1991) and Ibourk, Maillard, Perelman, and Sneessens 
(2001), we apply a stochastic production frontier approach to model the matching process. However, Warren (1991) estimates stochastic matching frontiers for the U.S. manufacturing sector, using only time series variation in the data, while Ibourk, Maillard, Perelman, and Sneessens (2001) also utilize spatial variation for French data on different labor market regions. In contrast, we estimate stochastic matching frontiers using panel data exhibiting cross-sectional variation across occupations and labor market regions. Both these dimensions are important from the perspective of labor market policies. The presented methodology is useful to investigate inefficiencies in the creation of new jobs. It allows to simultaneously estimate the parameters of the stochastic production frontier and the extent and determinants of the inefficiencies involved in the job creation process. Since the data used are longitudinal, we can additionally identify intertemporal changes in the matching frontier as well as variations in the inefficiencies over time.

The explicit consideration of inefficiencies raises issues of productivity versus inefficiency. The productivity of the stocks of job searchers and vacant positions in terms of creating a new employment relation has been studied before (see Petrongolo and Pissarides (2001) for an overview, and Fahr and Sunde (2001b) and Fahr and Sunde (2002) for respective studies on occupational and regional matching functions). If the elasticity of new matches with respect to these determinants is high in a certain occupation or region, these stocks exhibit a high matching productivity. However, if at the same time inefficiencies are high, an increase in the stocks would lead to fewer new matches than technically feasible. In such an environment, policies like e.g. the creation of subsidized vacancies or an intensification of immigration may turn out to be prohibitively costly and counter-productive. Instead, policies that aim at reducing the inefficiencies would be advisable. On the other hand, finding high efficiency estimates given the stocks of unemployed and vacancies as inputs indicates that creating a vacancy or increasing the available labor force in the respective occupation or region (e.g. via immigration policies) would indeed lead to additional job creation with high probability. Of course, in labor markets exhibiting high levels of matching efficiency, but low productivity, the objective for the policymaker should be to increase the productivity. ${ }^{1}$ The methodology used in this paper allows to identify the efficiency of distinct labor markets with respect to matching. In addition we are able to control for determinants influencing the inefficiency of the matching process within an occupation or region.

Hence, this paper provides much deeper insights into the matching pro-

\footnotetext{
${ }^{1}$ In other words, the matching technology itself is to be improved in such a scenario, for example by providing means that facilitate the encounter of appropriate vacancies by job seekers and thereby extend the matching possibilities frontier. Policies which solely target the demand or supply side by augmenting the stocks have little effects on employment inflows in such an environment, as have policies that aim at reducing inefficiencies.
} 
cess than previous contributions. Specifically, the approach in this paper is superior to the mismatch indices proposed in the literature, which try to identify inefficiencies in the matching process in occupations, e.g. by Jackman, Layard, and Savouri (1991) and Layard, Nickell, and Jackman (1991).

The paper proceeds as follows. Section 2 introduces the stochastic frontier framework used in the empirical application. Section 3 briefly describes sources and interesting features of the data used. In section 4 we present the main results of our investigations of different occupations, and in section 5 we explore the matching efficiency of different regional labor markets in West Germany. Section 6 concludes.

\section{The Stochastic Production Frontier Model}

The stochastic frontier production function has been studied extensively in production research and agricultural economics, see Bauer (1990), Coelli, Rao, and Battese (1998), and Morrison-Paul (1998, chapter 8) for extensive surveys of the literature and the techniques involved. In what follows, we adopt the approach proposed by Battese and Coelli (1995).

As is standard in the labor matching context, the flow of new matches in occupation $i=1,2, \ldots, N$ during time period $t=1,2, \ldots, T$ (more precisely between $t$ and $t+1), m_{i t}$, is a function of the stocks of unemployed job seekers of occupation $i$ in period $t, u_{i t}$, and vacancies $v_{i t}$. However, unlike in the conventional empirical matching framework, see Petrongolo and Pissarides (2001) for a survey, we explicitly include inefficiency in the matching process. Consider the following model:

$$
m_{i t}=A u_{i t}^{\alpha} v_{i t}^{\beta} e^{\tau+\varepsilon_{i t}-R_{i t}},
$$

where $\tau$ denotes a linear time trend, $A$ is total matching productivity, and $\alpha$ and $\beta$ are parameters to be estimated. $\varepsilon_{i t}$ is an i.i.d. $N\left(0, \sigma_{V}^{2}\right)$ error. $R_{i t}$ represents technical inefficiency of the matching process. We estimate several specifications of this key element of the stochastic frontier framework.

In the simpler specification of model $I$, following Battese and Coelli (1992), the technical inefficiency can vary over time:

$$
R_{i t}=\eta_{i t} R_{i}=e^{-\eta(t-T)} R_{i}
$$

where $\eta$ is an unknown parameter to be estimated, and the $R_{i}$ 's are assumed to be i.i.d non-negative truncations of the normal distribution with mean $\mu$ and variance $\sigma_{R}^{2}: N\left(\mu, \sigma_{R}^{2}\right)$. In this model, the non-negative occupation effects $R_{i}$ decrease, remain constant, or increase over time, if $\eta>0, \eta=0$ or $\eta<0$, respectively. ${ }^{2}$ Increasing efficiency over time may be interpreted

\footnotetext{
${ }^{2}$ When interpreting the results, we refrain from analyzing the shape of the temporal
} 
as learning of the agents how to find appropriate partners in order to form matches.

In a more general framework, the inefficiency term $R_{i t}$ can itself be a function of a set of explanatory variables. In model $I I$, technical inefficiency $R_{i t}$ is then specified as:

$$
R_{i t}=Z_{i t} \delta+\omega_{i t} .
$$

$Z_{i t}$ is a $(1 \times k)$ vector (of realizations of) a set of $k$ explanatory variables, and the process is described by a $(k \times 1)$ vector of unknown coefficients $\delta$. The first element of the $Z$-vector, $Z_{0}$, is a constant. Furthermore, $Z$ contains a deterministic time trend, so if the coefficients for all other elements of the $Z$-vector are equal to zero, the model essentially collapses to the simple specification in (2). ${ }^{3}$ The random variable $\omega_{i t}$ is a non-negative truncation of the normal distribution with zero mean and variance $\sigma_{\omega}^{2}$. The truncation point for $R_{i t}$ is $-Z_{i t}$, i.e. $\omega_{i t} \geq-Z_{i t} \delta$, so $R_{i t}$ is a non-negative truncation of the normal distribution with $N\left(Z_{i t} \delta, \sigma_{\omega}^{2}\right)$. Essentially, this specification parameterizes the mean of the inefficiency term $(\mu$ in $(2))$.

We estimate the specifications of the inefficiency effect, (2) and (3), respectively, simultaneously with the parameters of the stochastic frontier model (1) using the method of maximum likelihood. ${ }^{4}$ The specification of the likelihood function makes use of the following reparameterizations: The total variance of the process of matching which is not explained by the exogenous stocks is denoted as $\sigma^{2}$, and the share of this total variance accounted for by the variance of the inefficiency effect is $\gamma$. For the two specifications of the inefficiency model, the total variance reads:

$$
\begin{aligned}
\sigma_{I}^{2} & =\sigma_{\varepsilon}^{2}+\sigma_{R}^{2}, \\
\text { and } \sigma_{I I}^{2} & =\sigma_{\varepsilon}^{2}+\sigma_{\omega}^{2},
\end{aligned}
$$

for model $I$ presented in Equation (2) and model $I I$, presented in Equation (3), respectively. The share of this variance explained by inefficiency is:

$$
\begin{aligned}
\gamma_{I} & =\frac{\sigma_{R}^{2}}{\sigma_{I}^{2}}, \\
\text { and } \gamma_{I I} & =\frac{\sigma_{\omega}^{2}}{\sigma_{I I}^{2}},
\end{aligned}
$$

pattern of efficiency. In the specification (2) technical efficiency is concave in the estimate of $\eta$, that is if $\eta>0$ technical efficiency increases at a decreasing rate over time, while if $\eta<0$, efficiency decreases at an increasing rate. Compare Battese and Coelli (1992) for more flexible specifications.

${ }^{3}$ Note that this requires an appropriate specification of the time trend. Note also that not including a constant intercept parameter $\delta_{0}$ in this specification would lead to biased estimation results, see Battese and Coelli (1995).

${ }^{4}$ Compare Battese and Coelli (1993) and Battese and Coelli (1995) for the derivation of the likelihood functions and the likelihood contributions of the variables of the model. 
for models $I$ and $I I$, respectively. Intuitively, $\gamma$ is a measure of the importance of inefficiency for the given model specification. A large $\gamma$ indicates the need for taking inefficiencies into account.

Following Battese and Coelli (1995), we define the technical efficiency of the matching process of the $i$-th occupation as:

$$
T E_{i t}=e^{-R_{i t}}=e^{-Z_{i t} \delta-\omega_{i t}} .
$$

\section{Data}

The data used for the analysis below are yearly data on unemployment, vacancies, employment levels and flows from registered vacancies to employment for Western Germany. The data are from official labor statistics and disaggregated at occupational level. Moreover, also data on the pools of job seekers and vacancies are disaggregated. In contrast to the help-wanted index frequently used in U.S. studies, the vacancy measure provides detailed information about all vacancies registered at local employment offices. The data are disaggregated by 82 occupational groups. ${ }^{5}$ The hirings are measured on the individual level and stem from an anonymized representative $1 \%$ sample of German social security records. The data are available for the years 1975-1995, but reports of flows from registered vacancies to employment on an occupational level start in 1980. Therefore the data set eventually contains information for the years 1980-1995 for 82 occupational groups.

The second data set is from the same source of individual social security records, but comprises regional information for 117 labor market regions in West Germany for the period 1980-1997. ${ }^{6}$ Since the flows are generated from individual social security data, flow measures can be created that explicitly distinguish the flows by source, that is whether a newly hired individual was previously employed in another, potentially neighboring region.

Moreover, both data sets allow to identify hirings within a year for each occupation and by source of hiring in terms of the previous job status of a newly hired individual. There are, however, some problems in the data concerning the distinction of hirings from unemployment and hirings from out of the labor force. Due to the fact that employment status is identified by social security payments, our measure of hirings from out of the labor force in fact measures hirings from out of the labor force as well as hirings from unemployment. The reason is that hirings of formerly self-employed, of individuals formerly employed in low-paid jobs, which are exempt from social security contributions, or of unemployed who participated in active

\footnotetext{
${ }^{5}$ Fahr and Sunde (2001b) provides a detailed description of the data used in the analysis. The appendix includes a list of the occupational groups.

${ }^{6}$ These data are described in more detail in Fahr and Sunde (2002). The appendix contains a list of all regional labor markets surveyed in the analysis.
} 
labor market policies are not counted as hirings from unemployment. Thus, our measure of hirings from unemployment underestimates the true number of hirings from unemployment. Since individuals with the just mentioned characteristics are contained in the measure of registered unemployed at employment offices, our preferred measure of employment inflows is hirings from non-employment. We also report estimations for all hirings as a robustness check. ${ }^{7}$ A potential measurement problem arises also in the spatial context, since hirings from out of the labor force are coded as hirings from a non-neighboring region due to the lack of further information. Therefore, our measure of hirings from non-neighboring regions may contain some wrongly coded hirings that actually involved no change in region or only a change between neighboring regions.

\section{Efficiency of Occupational Matching}

In this section we present results of the estimation of Models $I$ and $I I$ for 82 occupational groups. ${ }^{8}$ While stochastic production frontier estimates have been applied to aggregate and regional matching functions, there exists no study to date that investigates variation across occupations. However, from the view point of the parties engaged in search on the labor market - unemployed and firms - this dimension is of particular importance, since occupation usually defines the skill requirements of a vacancy and characterizes the skill of a person searching for a job. In this sense, occupations define a relevant labor markets when studying the matching process of unemployed and vacancies.

The main estimation results are reported in Table 1 . The dependent variables are all matches within the respective period and matches of previously non-employed individuals, who successfully found a job in the respective period. ${ }^{9}$ Columns (1) and (2) contain the results for all hirings and hirings from non-employment in the specification of Model $I$, respectively. The estimated coefficients for the elasticity of all matches with respect to unemployment and vacancies are significantly positive, with the unemployment elasticity of just below 36 percent being 16 percent larger than the vacancy elasticity. For matches from non-employment, the unemployment elasticity

\footnotetext{
${ }^{7}$ See Fahr and Sunde (2001b) for a more detailed analysis of different concepts of employment flows and their determinants.

${ }^{8}$ Due to the similarity of the elasticity estimates of both specifications, the higher informational content of Model II and the availability of relevant data, we restrict ourselves to presenting estimation results for the specification of model $I I$ in the remainder of the paper. All estimations were done using the Frontier 4.1 program developed by Battese and Coelli (1995).

${ }^{9}$ Matches from non-employment are preferable to matches from unemployed, because the latter do not include inflows into new jobs by individuals currently participating in training programmes or participating in active labor market programmes, see Fahr and Sunde (2001a) for a detailed discussion of this issue.
} 
is even larger at above 43 percent, while the vacancy elasticity is about the same as for all matches with below 22 percent. These differences across specifications can be the result of systematic biases, adverse selection, or inherently different matching processes. ${ }^{10}$ The time trend is negative but insignificant for both employment flow concepts. However, the estimates for the share of variance of the dependent variable explained by inefficiencies, which lie above 85 percent in both specifications, indicate the need for a more thorough analysis of the determinants of these inefficiencies.

This is done in Columns (3) and (4), which provide estimation results for a Model $I I$ specification for all matches and matches from non-employment, respectively, with a constant, the fractions of young $(<25$ years $)$ and old ( $>50$ years) individuals in the respective workforce in a given occupation, the respective labor market tightness in the occupation as perceived by firms and measured by the logged ratio of vacancies over unemployed, and a time trend as determinants of the inefficiency term $Z$. The estimated coefficients of the matching elasticities are for both concepts of matches larger than those obtained from the Model $I$ specification, and the differences with respect to the flow concept used as dependent variable are negligible. The determinants of the inefficiency term exhibit consistently the same qualitative effects: Both a higher fraction of young and of old workers in a given occupation is associated with a significantly higher overall matching efficiency. ${ }^{11}$ Similarly, a higher labor market tightness in a given occupation facilitates the matching of unemployed and vacancies significantly. Moreover, inefficiencies significantly decreased over time in both cases, as indicated by the negative time trends. In both cases, the high estimated values of $\gamma_{I I}$ indicate the importance of the inefficiency term for explaining the variation in the dependent flows.

Using these estimation results, one can rank occupations according to their efficiency of matching unemployed and vacancies by comparing the respective time averages of the matching efficiencies $T E_{i}$ as defined in Equation 8. Table 2 presents the five occupations with the highest efficiency and the five occupations with the lowest efficiency over the period 1980 to 1995. ${ }^{12}$ The underlying estimation results are the corresponding columns of Table 1. At first sight, the results obtained by Model II differ somewhat from those of Model $I$, but this has mainly to do with the restriction to five occupations at each end of the spectrum. However, even then, some occupations exhibit consistently extreme efficiencies in comparison to all other occupations. Nurses (occupation 74) rank among those occupations with the highest matching efficiencies regardless of the model specification and

\footnotetext{
${ }^{10}$ See Kugler and Saint-Paul (2001), Fahr and Sunde (2001a) and Sunde (2002) for the respective potential explanations.

${ }^{11}$ The negative sign of the respective fractions of young and old workers indicate that inefficiencies are decreased.

${ }^{12}$ The occupation categories are listed in Table A1 in the appendix.
} 
TABLE 1:

Stochastic Production Frontier estimates of HiRing EFFiCIENCY OF OCCUPATIONS, 1981-1995.

\begin{tabular}{|c|c|c|c|c|}
\hline & \multicolumn{4}{|c|}{ Dependent variable: logarithm of hirings per occupation and year } \\
\hline & \multicolumn{2}{|c|}{ MODEL $I$} & \multicolumn{2}{|c|}{ MODEL $I I$} \\
\hline & $\begin{array}{l}(1) \\
\text { all }\end{array}$ & $\begin{array}{c}(2) \\
\text { from non-employment }\end{array}$ & $\begin{array}{l}(3) \\
\text { all }\end{array}$ & $\begin{array}{c}\text { (4) } \\
\text { from non-employment }\end{array}$ \\
\hline & $\ln \left(m_{a l l}\right)$ & $\ln \left(m_{X}\right)$ & $\ln \left(m_{a l l}\right)$ & $\ln \left(m_{X}\right)$ \\
\hline Log unemployed: $\ln U$ & $\begin{array}{c}0.358 \\
(0.022)\end{array}$ & $\begin{array}{c}0.435 \\
(0.021)\end{array}$ & $\begin{array}{c}0.484 \\
(0.017)\end{array}$ & $\begin{array}{c}0.472 \\
(0.024)\end{array}$ \\
\hline $\begin{array}{l}\text { Log registered } \\
\text { vacancies: } \ln V\end{array}$ & $\begin{array}{c}0.200 \\
(0.013)\end{array}$ & $\begin{array}{c}0.217 \\
(0.015)\end{array}$ & $\begin{array}{c}0.363 \\
(0.016)\end{array}$ & $\begin{array}{c}0.362 \\
(0.217)\end{array}$ \\
\hline time trend & $\begin{array}{l}-0.003 \\
(0.004)\end{array}$ & $\begin{array}{l}-0.020 \\
(0.546)\end{array}$ & $\begin{array}{l}-0.043 \\
(0.004)\end{array}$ & $\begin{array}{l}-0.046 \\
(0.005)\end{array}$ \\
\hline constant & $\begin{array}{c}6.576 \\
(0.320)\end{array}$ & $\begin{array}{c}5.286 \\
(0.276)\end{array}$ & $\begin{array}{c}3.552 \\
(0.110)\end{array}$ & $\begin{array}{l}3.438 \\
(0.124)\end{array}$ \\
\hline$\mu$ & $\begin{array}{c}1.290 \\
(0.132)\end{array}$ & $\begin{array}{c}1.056 \\
(0.176)\end{array}$ & & \\
\hline$\eta$ & $\begin{array}{l}-0.011 \\
(0.264)\end{array}$ & $\begin{array}{l}-0.009 \\
(0.004)\end{array}$ & & \\
\hline $\begin{array}{l}\text { Inefficiency term } Z \text { : } \\
\text { constant }\end{array}$ & & & $\begin{array}{l}1.754 \\
(0.267)\end{array}$ & $\begin{array}{c}1.584 \\
(0.256)\end{array}$ \\
\hline fraction young $(<25)$ & & & $\begin{array}{l}-7.560 \\
(2.218)\end{array}$ & $\begin{array}{l}-10.25 \\
(2.028)\end{array}$ \\
\hline fraction old $(>50)$ & & & $\begin{array}{l}-4.587 \\
(1.166)\end{array}$ & $\begin{array}{l}-4.735 \\
(0.920)\end{array}$ \\
\hline $\begin{array}{l}\text { labor market tightness } \\
\log (V / U)\end{array}$ & & & $\begin{array}{l}-0.134 \\
(0.062)\end{array}$ & $\begin{array}{l}-0.173 \\
(0.061)\end{array}$ \\
\hline time trend & & & $\begin{array}{l}-0.086 \\
(0.022)\end{array}$ & $\begin{array}{l}-0.052 \\
(0.017)\end{array}$ \\
\hline$\sigma_{I}^{2}$ & $\begin{array}{c}0.471 \\
(0.052)\end{array}$ & $\begin{array}{c}0.632 \\
(0.145)\end{array}$ & & \\
\hline$\sigma_{I I}^{2}$ & & & $\begin{array}{c}0.508 \\
(0.119)\end{array}$ & $\begin{array}{c}0.892 \\
(0.151)\end{array}$ \\
\hline$\gamma_{I}$ & $\begin{array}{c}0.884 \\
(0.010)\end{array}$ & $\begin{array}{c}0.855 \\
(0.034)\end{array}$ & & \\
\hline$\gamma_{I I}$ & & & $\begin{array}{c}0.657 \\
(0.093)\end{array}$ & $\begin{array}{c}0.818 \\
(0.034)\end{array}$ \\
\hline Log (likelihood) & -141.237 & -439.754 & -821.588 & -921.110 \\
\hline 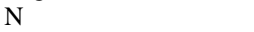 & 1230 & 1230 & 1230 & 1230 \\
\hline
\end{tabular}


Table 2: Predicted Efficiencies With Stochastic Frontier Model $I$ and $I$. OCCUPATIONS WITH HIGHEST AND LOWEST TECHNICAL EFFICIENCY BY SOURCE OF HIRING

\begin{tabular}{|c|c|c|c|c|c|c|c|c|}
\hline \multirow{3}{*}{$\begin{array}{l}\text { Source of Hiring: } \\
\text { Specification (cf. Table 1) }\end{array}$} & \multicolumn{4}{|c|}{ MODEL I } & \multicolumn{4}{|c|}{ MODEL $I I$} \\
\hline & \multicolumn{2}{|c|}{$\begin{array}{c}\boldsymbol{m}_{\text {all }} \\
\text { (1) }\end{array}$} & \multicolumn{2}{|c|}{$\begin{array}{c}\boldsymbol{m}_{X} \\
(2)\end{array}$} & \multicolumn{2}{|c|}{$\begin{array}{c}\boldsymbol{m}_{\text {all }} \\
\text { (3) }\end{array}$} & \multicolumn{2}{|c|}{$\begin{array}{c}\boldsymbol{m}_{X} \\
\text { (4) }\end{array}$} \\
\hline & occ. no. & eff. & occ. no. & eff. & occ. no. & eff. & occ. no. & eff \\
\hline Rank 1 & 67 & 0.978 & 67 & 0.944 & 79 & 0.925 & 5 & 0.900 \\
\hline Rank 2 & 74 & 0.867 & 5 & 0.908 & 1 & 0.923 & 79 & 0.890 \\
\hline Rank 3 & 57 & 0.866 & 42 & 0.878 & 37 & 0.916 & 10 & 0.879 \\
\hline Rank 4 & 58 & 0.705 & 74 & 0.873 & 5 & 0.913 & 74 & 0.876 \\
\hline Rank 5 & 42 & 0.694 & 57 & 0.790 & 74 & 0.906 & 42 & 0.875 \\
\hline Rank 78 & 35 & 0.091 & 18 & 0.121 & 23 & 0.609 & 23 & 0.433 \\
\hline Rank 79 & 32 & 0.087 & 32 & 0.119 & 54 & 0.516 & 54 & 0.388 \\
\hline Rank 80 & 8 & 0.071 & 70 & 0.092 & 2 & 0.466 & 77 & 0.340 \\
\hline Rank 81 & 70 & 0.063 & 8 & 0.072 & 77 & 0.401 & 70 & 0.310 \\
\hline Rank 82 & 2 & 0.050 & 2 & 0.062 & 70 & 0.388 & 2 & 0.294 \\
\hline
\end{tabular}

the concept of flows used as dependent variable.

At the other end of the ranking, agricultural administrators (occupation 2), law related professions (occupation 70), spinners (occupation 32) and chemists, physicists and scientists (occupations 54 and 77) exhibit the lowest efficiency in matching job seekers and vacant jobs. It is striking how large the variation between the highest scoring and the lowest scoring occupations is in terms of matching efficiency, in particular for Model $I$ estimates, where occupations exhibit efficiencies from 5 to 98 percent. The extended specification of Model $I I$ leads to less dispersed results, but still efficiency estimates vary between 30 and 92 percent.

Since this analysis concentrates on the average efficiencies of occupations over the entire observation period 1980 to 1995, the picture might be flawed if average matching efficiencies and the relative performance of occupations vary considerably over time. However, closer inspection reveals that the correlation between the efficiency ranking in 1980 and in 1995 lies between 76 and 80 percent for all four specifications. This indicates that the relative ordering is quite stable over time and re-inforces the relevance of the findings reported before.

To investigate more what determines matching efficiencies and the differences across occupations, we regress technical efficiency estimates on turnover and squared turnover in the respective occupation, as well as on the employment level. ${ }^{13}$

Table 3 presents results of regressions of predicted values of matching efficiency on the log of turnover and the squared log of turnover in the respective occupation as measured by the respective matches over the number of employed in the respective occupation-year cell, and log employment.

\footnotetext{
${ }^{13}$ All regressors enter the estimation equation in logged form to allow for interpretation as elasticities.
} 
TABLE 3:

DETERMINANTS OF HIRING EFFICIENCY OF OCCUPATIONS, 1981-1995.

\begin{tabular}{lcccc}
\hline \multicolumn{2}{c}{ Dependent variable: Average technical matching efficiency of occupation over the } \\
period 1981-1995
\end{tabular}

The specifications exhibited in columns (1') to (4') correspond to the specifications displayed in Table 1. The results for both flow concepts, all hires and hires from non-employment, in a Model $I$ specification, presented in columns (1') and (2') respectively, show that all three regressors exhibit significantly positive effects. In the Model $I I$ specifications of columns (3') and (4'), turnover and employment still significantly increase matching efficiency, while squared turnover has no measurable effect. Apparently, the more volatile and 'flexible' a given occupational labor market is, the more efficient is the matching process between unemployed and vacancies. Likewise the larger the respective labor market, the higher the efficiency estimate, suggesting that on average the search process leads to a match in shorter time if there are more individuals and firms involved in search.

\section{$5 \quad$ Efficiency of Regional Matching}

Instead of using the variation across occupations, many previous studies of the matching process investigated variation across regions, see Petrongolo and Pissarides (2001) for an overview. Ibourk, Maillard, Perelman, and Sneessens (2001) applied a stochastic matching frontier framework on French data. In this section, we analyze the matching process of 117 West-German regions using yearly data from 1980 to 1997. Table 4 presents results for estimations of specifications of Model $I I .{ }^{14}$ Due to the richness of the data,

\footnotetext{
${ }^{14}$ Estimation results for Model $I$ are qualitatively identical and are available upon request.
} 
it is possible to identify matches with respect to the region of origin of the hiree. Column (5) presents results for a full specification of Model II with all hirings of non-employed individuals in a given period and in a given region as dependent variable. ${ }^{15}$ The explanatory variables are the local stocks of unemployed and vacancies, the stocks of unemployed and vacancies in neighboring regions, and the respective stocks in non-neighboring regions. The stocks of job searchers and vacancies in non-neighboring regions do not affect matches significantly. Stocks in neighboring regions tend to significantly decrease matches, presumably because of competition effects between local and non-local job search. ${ }^{16}$ Local unemployment and vacancies enter significantly positive. Similar to the results obtained for occupations in the previous section, the elasticity of matches from non-employment with respect to unemployed is, with a value of 52 percent, larger than that with respect to vacancies (34 percent). The time trend is significantly negative, indicating a decrease in total matching efficiency over time.

The specification of the inefficiency term $Z$ is an extended version of the specification used for occupations above. The collinearity of occupations with education (some occupations only contain individuals of a certain education level, such that the knowledge of the education status does not add any new information) prevented the use of education levels in the previous chapter. However, for regions as the units of interest, the composition of the regional labor force with respect to educational background seems a relevant factor for explaining matching efficiencies. Therefore, we add the fractions of the employed labor force that exhibits low education and high education as additional explanatory variables in the efficiency term $Z$. As low education, we define individuals who neither successfully completed high school (Abitur), nor obtained a vocational degree. Individuals have high education, if they hold a degree from a university or an applied university (Fachhochschule). As for occupations, the other explanatory variables are the fraction of young and old workers, and labor market tightness as perceived by firms, as well as a linear time trend.

As with occupations, the higher the fraction of young individuals in the labor force, the lower the inefficiencies in the regional matching process. The influence of the fraction of old individuals is not significant, however. Somewhat surprisingly, the higher the fraction of people with a low educational background, the lower the matching inefficiency. This might have to do with the fact that these individuals are hired for jobs without particular require-

\footnotetext{
${ }^{15}$ Employment inflows of non-employed reflect the relevant flow concept in a matching framework that concentrates on unemployed job seekers, and are therefore the most preferred specification. For brevity, we therefore present only estimation results for matches from non-employment as dependent variable. The results for all matches as dependent variable are almost identical, however, and are available upon request.

${ }^{16}$ In a companion paper we look at inter-regional mobility and job competition in more detail, see Fahr and Sunde (2002).
} 
Table 4: Stochastic Matching Frontier estimates of HiRing EfFiciency Of REGIONS, 1980-1997.

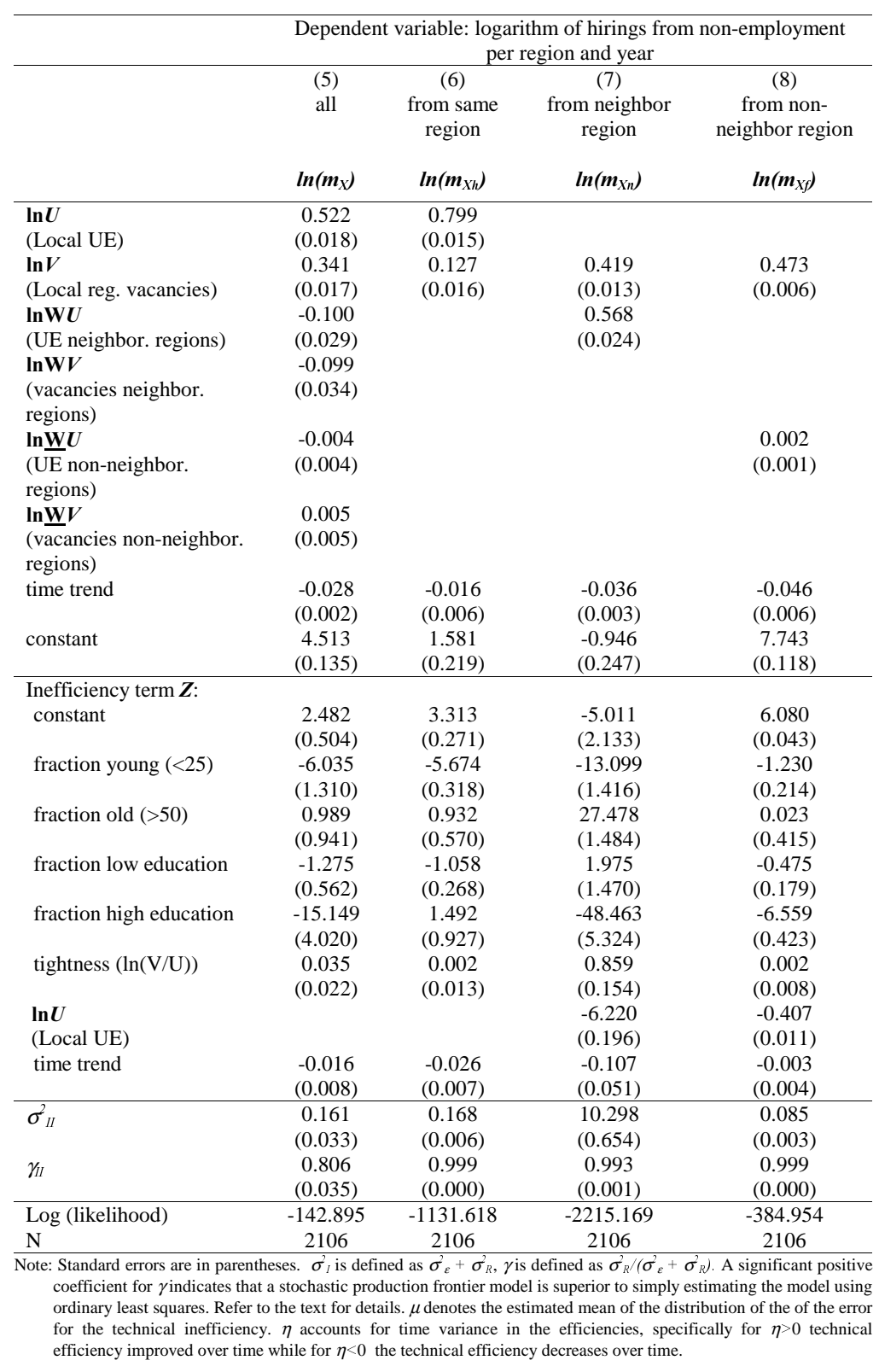


ments, and therefore are not screened very carefully, which facilitates the matching. But also the more individuals with high education populate the labor market, the more efficient the matching of unemployed and vacancies. This seems contradictory, but might have to do with the fact that higher search efficiency of highly educated individuals, as well as more directed search on both sides of this segment of the labor market might overcompensate more stringent screening requirements. Note, that quantitatively the effect of the fraction of highly educated is almost twelve times as high as the one for the fraction with low education. Finally, the tighter the labor market, the more inefficient the matching process, presumably since search frictions in the form of coordination problems increase when firms obstruct each other in the search for new employees. Overall, variation in the inefficiency term explains about 80 percent of the total variation of all matches from non-employment.

In column (6), we present estimation results for matches of individuals who were non-employed before encountering the new match, but whose previous employer was located in the same region as their new one. Explanatory variables are local stocks of unemployed and vacancies. Again, both enter significantly positive, but the impact of unemployment is much larger than in the specification for non-employed matches from all regions, with a coefficient estimate of 0.8 , while the vacancy elasticity of matches is only around 0.13. The time trend is negative. As for the inefficiency term, all effects are qualitatively the same as for specification (5) with one exception. The fraction of highly educated individuals now tends to increase inefficiency, but this effect is not significantly different from zero. Also in contrast to the results for all matches from non-employment, the variation in the inefficiency term explains virtually all the variation in matches of non-employed, local individuals.

The same result is found for matches of non-employed, who were previously employed in neighboring regions (column 7), and in non-neighboring regions (column 8) as dependent variable. In these two specifications, the flow of new matches is regressed on the stock of local vacancies, and the stock of unemployment in neighboring and non-neighboring regions, respectively. These are the relevant stocks, since employment inflows are recorded in the region under observation, such that only local vacancies can account for their creation. But since the inflows explicitly contain non-employed individuals with origin in neighboring or non-neighboring regions, they must have been contained in the unemployment pool of their respective region of origin, and not the destination region.

For flows from neighboring regions (column 7), local vacancies and unemployment in neighboring regions significantly increase job creation, but now the elasticity with respect to vacancies is relatively higher. Also the results for the determinants of matching inefficiencies exhibit some novel features. The more young workers are in the labor force in a region, the higher the 
efficiency of the matching process involving individuals from neighboring regions. Conversely, the more old workers are in the labor market, the more inefficient the matching process becomes. This stands also in contrast to the results previously obtained for occupations. Moreover, the larger the fraction of people with low education background the lower the matching efficiency, although this effect is not significant. However, the higher the share of highly educated workers, the more efficient the matching process becomes. Again, also higher local labor market tightness renders matching less efficient. As a further potential determinant of inefficiencies in the matching process, the local unemployment rate is included to capture competition effects between unemployed in neighboring regions and local unemployed. But the estimates show that the higher the local unemployment stock, the more efficient is the matching process with respect to applicants from neighboring regions.

When matches of non-employed from non-neighboring regions are the dependent variable (column 8), vacancies still exhibit a large positive and significant effect, while unemployment in non-neighboring regions has no effect on matches at all. While the time trend is significantly negative as in all other specifications, the determinants of the inefficiency term differ somewhat. Again, the number of young increases efficiency, but the number of old has no impact. Both, the fraction of workers with high and with low educational background significantly increase the efficiency of matches from non-neighboring regions. The tightness of the local labor market has no effect. Similar to the results for inflows from neighboring regions, higher local unemployment rates decrease inefficiencies in the matching process of applicants from non-neighboring regions.

As with occupations, also regions can be ranked with respect to their matching efficiency estimates. The resulting rankings of the five regions with the highest and the five with the lowest matching efficiencies for the same specifications as displayed in Table 4 are presented in Table 5. Apparently, for all matches from non-employment (specification 5), southern regions around Munich (regions 112, 113, 114) exhibit particularly high matching efficiencies, while rural, thinly populated areas in Northern Germany exhibit the relatively lowest efficiency estimates. The picture changes when one looks at matches from the same region. The highest efficiencies are found in regions which are relatively remote from major urban areas, and which obviously recruit most of their hirees from within the same region. On the other hand, the lowest respective efficiency estimates are found for densely populated areas like in the Ruhr area, or in regions which neighbor major urban agglomeration areas. Interestingly, major cities like Frankfurt (region 51), Bremen (region 7), Cologne (region 39), Hamburg (region 2) and Düsseldorf (region 33) are the five areas exhibiting the highest efficiencies for matches from neighboring regions. Apparently, these cities attract people from surrounding regions, while remote areas close to borders or far 
Table 5: Predicted EfFiciencies With Stochastic Frontier Model II. Regions WITH HIGHEST AND LOWEST TECHNICAL EFFICIENCY.

\begin{tabular}{|c|c|c|c|c|c|c|c|c|}
\hline \multirow[t]{2}{*}{$\begin{array}{l}\text { Specification (cf. } \\
\text { Table 3) }\end{array}$} & \multicolumn{2}{|c|}{$\begin{array}{l}\boldsymbol{m}_{X} \\
\text { (all) }\end{array}$} & \multicolumn{2}{|c|}{$\begin{array}{c}\boldsymbol{m}_{\boldsymbol{X}} \\
\text { (from home } \\
\text { region) } \\
(6)\end{array}$} & \multicolumn{2}{|c|}{$\begin{array}{l}\boldsymbol{m}_{X} \\
\text { (from neighbor } \\
\text { region) } \\
(7)\end{array}$} & \multicolumn{2}{|c|}{$\begin{array}{c}\boldsymbol{m}_{\boldsymbol{X}} \\
\text { (from non-neighbor } \\
\text { region) } \\
(8)\end{array}$} \\
\hline & region & eff. & region & eff. & region & eff. & region & eff. \\
\hline Rank 1 & 113 & 0.932 & 113 & 0.799 & 51 & 0.861 & 2 & 0.769 \\
\hline Rank 2 & 112 & 0.926 & 93 & 0.669 & 7 & 0.823 & 112 & 0.598 \\
\hline Rank 3 & 114 & 0.926 & 103 & 0.614 & 39 & 0.816 & 51 & 0.545 \\
\hline Rank 4 & 93 & 0.920 & 58 & 0.538 & 2 & 0.808 & 89 & 0.527 \\
\hline Rank 5 & 19 & 0.923 & 96 & 0.519 & 33 & 0.790 & 39 & 0.504 \\
\hline Rank 113 & 10 & 0.531 & 40 & 0.118 & 22 & 0.247 & 3 & 0.109 \\
\hline Rank 114 & 64 & 0.529 & 28 & 0.091 & 17 & 0.237 & 110 & 0.105 \\
\hline Rank 115 & 16 & 0.503 & 8 & 0.089 & 79 & 0.202 & 17 & 0.101 \\
\hline Rank 116 & 17 & 0.475 & 17 & 0.080 & 3 & 0.196 & 16 & 0.094 \\
\hline Rank 117 & 8 & 0.387 & 80 & 0.080 & 116 & 0.186 & 8 & 0.091 \\
\hline
\end{tabular}

away from agglomeration centers exhibit the lowest respective efficiencies. Finally, cities like Hamburg (region 2), Munich (region 112), Frankfurt (region 51), Stuttgart (region 89) and Cologne (region 39) are also those with the highest efficiency estimates for matches from non-neighboring regions, and successfully attract hirees from regions located further away. Again, remote, rural areas exhibit the opposite feature of extremely low matching efficiencies in this respect.

Regressing predicted efficiency estimates on turnover, squared turnover and employment, as was already done for occupations in the last section, delivers estimation results displayed in Table 6 . These results are considerably heterogeneous and not straightforward to interpret. While for all matches from non-employment as dependent variable the matching efficiency is higher the higher the turnover in the respective cell, the opposite is true when more spatial structure is added and matches are distinguished by geographic provenance of the hirees: Inefficiencies increase as turnover becomes higher. With the exception of all matches, the squared turnover effect is insignificant, which might explain some of the differences in the coefficient estimates for the linear term. The higher the employment level in a given region, the less efficient the matching process for non-employed, as well as for non-employed from neighboring and from non-neighboring regions. In contrast, higher employment levels increase the efficiency of the matching process of local job seekers. This result indicates that there might be something like a home field advantage with respect to search frictions and competition for vacant jobs.

Summing up, regional disaggregation exhibits similarly interesting insights into the matching process as occupational disaggregation. However, the direct implications for economic policy are a lot less clear, and depend on the specific objective that a given intervention pursues. 
TABLE 6:

DETERMINANTS OF HIRING EFFICIENCY OF REgONS, 1980-1997.

\begin{tabular}{|c|c|c|c|c|}
\hline \multirow{5}{*}{$\begin{array}{c}\text { Dependent variable in } \\
\text { underlying } \\
\text { specification: hirings } \\
\text { from non-employment }\end{array}$} & \multicolumn{4}{|c|}{$\begin{array}{l}\text { Dependent variable: Average technical matching efficiency of region over the } \\
\text { period } 1980-1997\end{array}$} \\
\hline & \multicolumn{2}{|c|}{ MODEL $I$} & \multicolumn{2}{|c|}{ MODEL $I I$} \\
\hline & $\left(5^{\prime}\right)$ & $\left(6^{\prime}\right)$ & $\left(7^{\prime}\right)$ & $\left(8^{\prime}\right)$ \\
\hline & (all) & (from same region) & $\begin{array}{c}\text { (from neighboring } \\
\text { region) }\end{array}$ & $\begin{array}{l}\text { (from non-neighboring } \\
\text { region) }\end{array}$ \\
\hline & $T E$ & $T E$ & $T E$ & $T E$ \\
\hline Log turnover: & -0.187 & 0.447 & 0.178 & 0.162 \\
\hline $\ln (m / e m p)$ & $(0.052)$ & $(0.188)$ & $(0.107)$ & $(0.050)$ \\
\hline Log turnover squared: & -0.117 & 0.035 & 0.007 & -0.000 \\
\hline $\ln (m / e m p)^{2}$ & $(0.013)$ & $(0.042)$ & $(0.025)$ & $(0.011)$ \\
\hline \multirow[t]{2}{*}{ log employment } & 0.077 & -0.012 & 0.169 & 0.178 \\
\hline & $(0.003)$ & $(0.004)$ & $(0.007)$ & $(0.003)$ \\
\hline \multirow[t]{2}{*}{ constant } & 0.021 & 1.188 & -1.078 & -1.495 \\
\hline & $(0.054)$ & $(0.180)$ & $(0.118)$ & $(0.056)$ \\
\hline $\mathrm{R}^{2}$ & 0.598 & 0.483 & 0.191 & 0.807 \\
\hline $\mathrm{N}$ & 1872 & 1872 & 1872 & 1872 \\
\hline
\end{tabular}

\section{Summary and Conclusion}

This paper has investigated the efficiency of the matching process of unemployed job seekers and vacancies. We provide some facts to the political discussion of how to reduce unemployment. There, on one side, some politicians favor policies that aim at improving the efficiency of the matching process, while others propose policies affecting the respective pools of employment seekers and vacancies, without presenting any evidence why their respective approach might be appropriate. Contrary to any previous study, we apply a stochastic matching frontier framework to data from West Germany which are disaggregated by occupations and regions. This allows to use and interpret cross-sectional variation in the matching process, and provides a method to evaluate the matching efficiency of different occupations and regions. Using this tool can help to guide policy makers considering appropriate interventions in particular labor markets. Combined with a detailed analysis of the relative importance of demand and supply factors in the job creation process in a given occupation or region, the method helps to identify labor markets where policies affecting the stocks of job seekers or vacancies are appropriate, or where, on the other hand, policies improving the efficiency of the matching process are preferable.

The findings indicate substantial differences in the efficiency of the matching process across occupations. For example, occupations like nurses exhibit very high efficiency estimates, indicating that supply and demand policies affecting the respective stocks of search participants can be quite useful to 
increase employment inflows. On the other hand, such policies have little effect for example in law related occupations, where the matching efficiency is very low.

Rather than by variation in the pools of job seekers and vacancies, much of the variation in employment inflows can be attributed to factors affecting the level of matching efficiency. Inefficiencies have been shown to be determined by the composition of the labor market with respect to the age and education structure, as well as the current labor market conditions as indicated by labor market tightness.

Similarly, disaggregation by region delivers a heterogeneous picture of the efficiency of the matching process. Of course, policy implications depend on the particular objective of policy interventions. The results for spatial disaggregation are per se interesting, and reveal the importance of considering regional labor markets and inefficiencies in their particular matching processes. The evidence presented in this paper indicated considerable differences between matching processes of individuals with different regional provenance and illustrated the importance of distinguishing flows by their respective source regions. But in terms of economic policy, the disaggregation across occupations seems to be more relevant than considering different regions, as has been done hitherto in the literature. 


\section{References}

Battese, G., and T. Coelli (1992): "Frontier Production Functions, Technical Efficiency and Panel Data: With Application to Paddy Farmers in India," Journal of Productivity Analysis, 3, 153-169.

Battese, G. E., And T. J. Coelli (1993): "A Stochastic Frontier Production Function Incorporating a Model for Technical Inefficiency Effects," Working Papers in Econometrics and Applied Statistics, Department of Econometrics, University of New England, Armidale, Australia.

(1995): "A Model for Technical Inefficiency Effects in a Stochastic Frontier Production Function for Panel Data," Empirical Economics, 20, $325-332$.

Bauer, P. W. (1990): "Recent Developments in the Econometric Estimation of Frontiers," Journal of Econometrics, 46, 39-56.

Coelli, T., D. P. Rao, and G. E. Battese (1998): An Introduction to Efficiency and Productivity Analysis. Kluwer Academic, Boston.

FAhr, R., And U. Sunde (2001a): "Strategic Hiring Behavior in Empirical Matching Functions," IZA Discussion Paper, 320.

_ (2001b): "Disaggregate Matching Functions," IZA Discussion Paper, 335 .

(2002): "Employment Status, Endogenous Regional Mobility, and Spatial Dependencies in Labor Markets," IZA Discussion Paper, 521.

Ibourk, A., B. Maillard, S. Perelman, and H. R. Sneessens (2001): "The Matching Efficiency of Regional Labour Markets: A Stochastic Production Frontier Estimation, France 1990-1995," IZA Discussion Paper, 339, IZA Discussion Paper.

Jackman, R., R. Layard, and S. Savouri (1991): Mismatch: A Framework for Thought. Cambridge University Press, Cambridge U.K.

Kugler, A. D., and G. Saint-Paul (2001): "How do Firing Costs affect Worker Flows in a World with Adverse Selection?," mimeo.

LAyARD, R., S. Nickell, AND R. JACKMAN (1991): Unemployment: Macroeconomic Performance and the Labour Market. Oxford University Press, Oxford.

Morrison-Paul, C. J. (1999): Cost Structure and the Measurement of Economic Performance. Kluwer Academic, Boston. 
Petrongolo, B., And C. Pissarides (2001): "Looking Into the Black Box: A Survey of the Matching Function," Journal of Economic Literature, 39(2), 390-431.

Sunde, U. (2002): "Unobserved Bilateral Search on the Labor Market: A Theory-Based Correction for a Common Flaw in Empirical Matching Studies," IZA Discussion Paper, 520.

WArren, R. S. (1991): "The Estimation of Frictional Unemployment: A Stochastic Frontier Approach," Review of Economics and Statistics, 73(2), $373-377$. 
TABLE A1: OCCUPATIONS

\begin{tabular}{|c|c|c|}
\hline Occupation & $\begin{array}{c}\text { Occupational codes } \\
\text { (2-digit, from official } \\
\text { statistics) }\end{array}$ & $\begin{array}{c}\text { Occupation } \\
\text { number }\end{array}$ \\
\hline farmer, fisher & 01 & 1 \\
\hline agricultural administrator & 03 & 2 \\
\hline $\begin{array}{l}\text { helper in the agricultural sector, agricultural } \\
\text { workers, stockbreeding professions }\end{array}$ & 04 & 3 \\
\hline gardener, florist & 05 & 4 \\
\hline forester and huntsman & 06 & 5 \\
\hline miner and related professions & 07 & 6 \\
\hline exhauster of mineral resources & 08 & 7 \\
\hline mineral rehasher, mineral burner & 09 & 8 \\
\hline stone processor & 10 & 9 \\
\hline ,producer of building materials & 11 & 10 \\
\hline ceramicist, glazier & 12 & 11 \\
\hline glazier, glass processor, glass refiner & 13 & 12 \\
\hline chemical worker & 14 & 13 \\
\hline polymer processor & 15 & 14 \\
\hline paper producer & 16 & 15 \\
\hline printer & 17 & 16 \\
\hline woodworker, wood processor & 18 & 17 \\
\hline metal worker & 19 & 18 \\
\hline moulder, caster, semi-metal cleaner & 20 & 19 \\
\hline metal press workers, metal formers & 21 & 20 \\
\hline turner, cutter, driller, metal polisher & 22 & 21 \\
\hline metal burnisher, galvanizer, enameler & 23 & 22 \\
\hline welder, solderer, riveter, metal gluter & 24 & 23 \\
\hline steel smith, copper smith & 25 & 24 \\
\hline plumber, plant locksmith & 26 & 25 \\
\hline locksmith, fitter & 27 & 26 \\
\hline mechanic & 28 & 27 \\
\hline toolmaker & 29 & 28 \\
\hline metal precision-workers, orthodontists, opticians & 30 & 29 \\
\hline electricians & 31 & 30 \\
\hline assemblers and metal related professions & 32 & 31 \\
\hline spinner, ropemaker & 33 & 32 \\
\hline weaver, other textile producer & 34 & 33 \\
\hline tailor, sewer & 35 & 34 \\
\hline textile dyer & 36 & 35 \\
\hline leather and fur manufacturers, shoemaker & 37 & 36 \\
\hline baker, confectioner & 39 & 37 \\
\hline butcher, fishworkmansip and related & 40 & 38 \\
\hline cooks, convenience food preparatory & 41 & 39 \\
\hline brewer, manufacturer for tobacco products & 42 & 40 \\
\hline milk/fat processor, nutriments producer & 43 & 41 \\
\hline bricklayer, concrete builder & 44 & 42 \\
\hline carpenter, roofer, spiderman & 45 & 43 \\
\hline $\begin{array}{l}\text { road/track constructors, demolisher, culture } \\
\text { structurer }\end{array}$ & 46 & 44 \\
\hline helper in the construction sector & 47 & 45 \\
\hline plasterer, tiler, glazier, screed layer & 48 & 46 \\
\hline interior designer, furniture supplier & 49 & 47 \\
\hline joiner, modeler, cartwright & 50 & 48 \\
\hline painter, varnisher and related professions & 51 & 49 \\
\hline goods tester, consignment professions & 52 & 50 \\
\hline unskilled worker & 53 & 51 \\
\hline machinist and related professions & 54 & 52 \\
\hline
\end{tabular}


Table A1 continued

\begin{tabular}{|c|c|c|}
\hline engineer, architect & 60 & 53 \\
\hline chemist, physicist & 61 & 54 \\
\hline technician & 62 & 55 \\
\hline technical specialist & 63 & 56 \\
\hline merchandise manager & 68 & 57 \\
\hline banking professional, insurance merchant & 69 & 58 \\
\hline $\begin{array}{l}\text { merchant/ specialist in conveyance, tourism, other } \\
\text { services }\end{array}$ & 70 & 59 \\
\hline conductor, driver, motorist & 71 & 60 \\
\hline navigator, ship engineer, water/air traffic professions & 72 & 61 \\
\hline mail distributer & 73 & 62 \\
\hline storekeeper, worker in storage and transport & 74 & 63 \\
\hline manager, consultant, accountant. & 75 & 64 \\
\hline member of parliament, association manager & 76 & 65 \\
\hline accounting clerk, cashier, data processing expert & 77 & 66 \\
\hline clerk, typist, secretary & 78 & 67 \\
\hline plant security, guard, gate keeper, servant & 79 & 68 \\
\hline $\begin{array}{l}\text { other security related professions, health caring } \\
\text { professions }\end{array}$ & 80 & 69 \\
\hline law related professions & 81 & 70 \\
\hline publicist, translator, librarian & 82 & 71 \\
\hline artist and related professions & 83 & 72 \\
\hline physician, dentist, apothecaries & 84 & 73 \\
\hline nurse, helper in nursing, receptionist and related & 85 & 74 \\
\hline social worker, care taker & 86 & 75 \\
\hline professor, teacher & 87 & 76 \\
\hline scientist & 88 & 77 \\
\hline helper for cure of souls and cult & 89 & 78 \\
\hline beauty culture & 90 & 79 \\
\hline guest assistant, steward, barkeeper & 91 & 80 \\
\hline domestic economy, housekeeping & 92 & 81 \\
\hline cleaning industry related professions & 93 & 82 \\
\hline trainee, apprentice & 98 & * \\
\hline
\end{tabular}


TABLE A2: REgIONAL LABOR MARKETS FOR WEST GERMANY

\begin{tabular}{|c|c|c|c|}
\hline $\begin{array}{r}\text { Region } \\
\text { number }\end{array}$ & Region & $\begin{array}{r}\text { Region } \\
\text { number }\end{array}$ & Region \\
\hline 1 & Flensburg & 64 & Landau \\
\hline 2 & Hamburg, incl. Bad Oldesloe, & 65 & Ludwigshafen \\
\hline & Elmshorn, Stade & 66 & Mainz \\
\hline 3 & Heide & 67 & Montabaur \\
\hline 4 & Kiel incl. Neumünster & 68 & Neuwied \\
\hline 5 & Lübeck & 69 & Pirmasens \\
\hline 6 & Braunschweig & 70 & Saarbrücken, incl. Neunkirchen, \\
\hline 7 & Bremen, incl. Bremerhaven, Verden & & Saarlouis \\
\hline 8 & Celle & 71 & Trier \\
\hline 9 & Emden & 72 & Aalen \\
\hline 10 & Goslar & 73 & Balingen \\
\hline 11 & Göttingen & 74 & Freiburg \\
\hline 12 & Hameln & 75 & Heidelberg \\
\hline 13 & Hannover & 76 & Heilbronn \\
\hline 14 & Helmstedt & 77 & Karlsruhe \\
\hline 15 & Hildesheim & 78 & Konstanz \\
\hline 16 & Leer & 79 & Lörrach \\
\hline 17 & Lüneburg & 80 & Mannheim \\
\hline 18 & Nienburg & 81 & Nagold \\
\hline 19 & Nordhorn & 82 & Offenburg \\
\hline 20 & Oldenburg & 83 & Pforzheim \\
\hline 21 & Osnabrück & 84 & Rastatt \\
\hline 22 & Uelzen & 85 & Ravensburg \\
\hline 23 & Vechta & 86 & Reutlingen \\
\hline 24 & Wilhelmshaven & 87 & Rottweil \\
\hline 25 & Aachen & 88 & Schwäbisch Hall \\
\hline 26 & Bergisch Gladbach & 89 & Stuttgart, incl. Göppingen, \\
\hline 27 & Bielefeld, incl. Herford & & Ludwigsburg, Waiblingen \\
\hline 28 & Bochum & 90 & Tauberbischofsheim \\
\hline 29 & Bonn & 91 & Ulm \\
\hline 30 & Detmold & 92 & Villingen-Schwenningen \\
\hline 31 & Dortmund, incl. Hamm & 93 & Ansbach \\
\hline 32 & Düren & 94 & Aschaffenburg \\
\hline 33 & Düsseldorf & 95 & Bamberg \\
\hline 34 & Duisburg., incl. Oberhausen, Wesel & 96 & Bayreuth \\
\hline 35 & Essen & 97 & Coburg \\
\hline 36 & Gelsenkirchen, incl. Recklinghausen & 98 & Hof \\
\hline 37 & Hagen & 99 & Nürnberg, incl. Weissenburg \\
\hline 38 & Iserlohn & 100 & Regensburg \\
\hline 39 & Köln, incl. Brühl & 101 & Schwandorf \\
\hline 40 & Krefeld & 102 & Schweinfurt \\
\hline 41 & Meschede & 103 & Weiden \\
\hline 42 & Mönchengladbach & 104 & Würzburg \\
\hline 43 & Münster, incl. Ahlen, Coesfeld & 105 & Augsburg \\
\hline 44 & Paderborn & 106 & Deggendorf \\
\hline 45 & Rheine & 107 & Donauwörth \\
\hline 46 & Siegen & 108 & Ingolstadt \\
\hline 47 & Soest & 109 & Kempten \\
\hline 48 & Wuppertal, incl. Solingen & 110 & Landshut \\
\hline 49 & Bad Hersfeld & 111 & Memmingen \\
\hline 50 & Darmstadt & 112 & München, incl. Freising \\
\hline 51 & Frankfurt, incl. Offenbach & 113 & Passau \\
\hline 52 & Fulda & 114 & Pfarrkirchen \\
\hline 53 & Gießen & 115 & Rosenheim \\
\hline 54 & Hanau & 116 & Traunstein \\
\hline 55 & Kassel & 117 & Weilheim \\
\hline 56 & Korbach & & \\
\hline 57 & Limburg & & \\
\hline 58 & Marburg & & \\
\hline 59 & Wetzlar & & \\
\hline 60 & Wiesbaden & & \\
\hline 61 & Bad Kreuznach & & \\
\hline 62 & Kaiserslauten & & \\
\hline 63 & Koblenz, incl. Mayen & & \\
\hline
\end{tabular}




\section{IZA Discussion Papers}

No. Author(s)

M. Orszag

D. Snower

D. Snower

G. Zoega

M. E. Ward

B. Cockx

M. Dejemeppe

542

M. Frölich

$$
\text { J. Darby }
$$$$
\text { R. A. Hart }
$$

P. Portugal

A. R. Cardoso

M. Fertig

C. M. Schmidt

$\begin{array}{ll}546 & \text { A. M. Stiglbauer } \\ & \text { F. Stahl } \\ & \text { R. Winter-Ebmer } \\ & \text { J. Zweimüller } \\ 547 & \begin{array}{l}\text { G. S. Epstein } \\ \text { I. N. Gang }\end{array} \\ 548 & \text { M. Frölich }\end{array}$

D. Clark

$$
\text { R. Fahr }
$$$$
\text { U. Sunde }
$$

Title

Area

Date

Pension Taxes versus Early Retirement Rights

3

$07 / 02$

Unemployment Vouchers versus Low-Wage

3

07/02

Subsidies

The Pension Transfer Program

3

07/02

Labour-Market Institutions and Macroeconomic

3

Shocks

$07 / 02$

High Skilled Migration and the Exertion of Effort 1

$08 / 02$

by the Local Population

Do the Higher Educated Unemployed Crowd Out

2

08/02

the Lower Educated Ones in a Competition for Jobs

Programme Evaluation with Multiple Treatments

08/02

Wages, Productivity, and Work Intensity in the 5

$08 / 02$

Great Depression

Disentangling the Minimum Wage Puzzle: An 3

Analysis of Worker Accessions and Separations

The Role of Background Factors for Reading

Literacy: Straight National Scores in the PISA 2000 Study

Job Creation and Job Destruction in a Regulated

2

Labor Market: The Case of Austria

$08 / 02$

Government and Cities: Contests and the

3

$08 / 02$

Decentralization of Decision Making

What is the Value of Knowing the Propensity

6

$08 / 02$

Score for Estimating Average Treatment

Effects?

Interpreting Europe and US Labor Markets

2

$08 / 02$

Differences: The Specificity of Human Capital Investments

The Impact of Local Labour Market Conditions 2 on Participation in Further Education in England

Herd Effects or Migration Networks?

The Location Choice of Mexican Immigrants in the U.S.

Estimations of Occupational and Regional

6

Matching Efficiencies Using Stochastic Production Frontier Models 